\title{
B4 - EFETIVIDADE DA ALFAINTERFERONA (+ RIBAVIRINA) NO TRATAMENTO DA HEPATITE VIRAL CRÔNICA C GENÓTIPOS 2 E 3 EM AMOSTRA BRASILEIRA
}

Candice Beatriz Treter Gonçalves ${ }^{1}$, Karine Medeiros. Amaral ${ }^{1}$, Guilherme Becker Sander $^{3}$, Norberto Luis Campos Martins ${ }^{1}$, Lisandra Pereira ${ }^{1}$, Paulo Dornelles Picon $^{2}$

(1) SES-RS, Porto Alegre, RS; (2)UFRGS, (3) HCPA

Estudos de farmacovigilância têm por objeto a detecção, avaliação, compreensão e prevenção dos riscos dos efeitos adversos dos medicamentos ou qualquer outro possível problema relacionado com medicamento. A alfainterferona (IFN) está sendo produzida por Bio-Manguinhos/Fiocruz e utilizada no tratamento da hepatite $\mathrm{C}$ crônica no âmbito do Sistema Único de Saúde (Sistema Único (SUS).

Objetivo: O objetivo principal deste estudo foi conhecer o perfil de segurança e efetividade deste IFN em uma amostra de pacientes brasileiros com hepatite crônica pelo vírus C genótipos 2 e 3, em Porto Alegre, Rio Grande do Sul.

Metodologia: Trata-se de uma coorte de pacientes com hepatite crônica pelo vírus C genótipos 2 e 3 tratados com IFN e ribavirina e acompanhados em um serviço ambulatorial especializado no sul do Brasil. Os eventos adversos foram coletados e classificados de acordo com a gravidade em entrevistas mensais estruturadas. Para medida de eficácia foi avaliada a carga viral do HCV antes, ao final e 24 semanas após o término do tratamento.

Resultados: Foram acompanhados 141 pacientes no período do estudo, sendo 52,5\% do sexo feminino com média de idade de 52 anos. Os eventos adversos mais freqüentes foram fadiga (84\%), cefaléia (79\%) e mialgia (75\%). Ocorreram 13 interrupções de tratamento por eventos adversos, sendo nove destes considerados eventos adversos graves. A resposta virológica ao final do tratamento foi de 54,6\% e 24 semanas após de $39,7 \%$, considerando todos os pacientes que iniciaram o tratamento. 
Conclusão: O produto produzido por Bio-Manguinhos possui eficácia e um perfil de eventos adversos e de resposta virológica sustentada comparáveis aos encontrados na literatura. Este foi o primeiro estudo de farmacovigilância realizado com o produto brasileiro. Estes dados serão úteis para planejamento e gestão do tratamento desta doença no Brasil. 